\title{
Pharmacognostic, chemical and mucolytic activity study of Malva pseudolavatera Webb \& Berthel. and Malva sylvestris L. (Malvaceae) leaf extracts, grown in Ecuador
}

\author{
GLENDA MARCELA SARMIENTO-TOMALÁ ${ }^{1}$, MIGDALIA MIRANDA-MARTÍNEZ ${ }^{2,3, \bullet}$, \\ IVÁN ANDRÉS CHÓEZ-GUARANDA ${ }^{2}$, YAMILET IRENE GUTIÉRREZ-GAITÉN ${ }^{4}$, \\ RENÉ DELGADO-HERNÁNDEZ ${ }^{5,6}$, GABRIELA CARRILLO-LAVID ${ }^{3}$ \\ ${ }^{1}$ Department of Chemical and Environmental Sciences. Faculty of Natural Sciences and Mathematics, Escuela Superior Politécnica del Litoral (ESPOL). \\ Campus Gustavo Galindo Km. 30.5 Vía Perimetral, P.O. Box 09-01-5863, Guayaquil, Ecuador. Tel.: +593 2269269, •email: mgmiran@espol.edu.ec \\ ${ }^{2}$ Ecuador Biotechnology Research Center, Escuela Superior Politécnica del Litoral (ESPOL). Campus Gustavo Galindo Km. 30.5 Vía Perimetral, P.O. \\ Box 09-01-5863, Guayaquil, Ecuador \\ ${ }^{3}$ Faculty of Chemical Sciences, University of Guayaquil. "Salvador Allende" University Citadel Ave., Kennedy S/N and Av. Delta, Guayaquil, Ecuador \\ ${ }^{4}$ Department of Pharmacy, Institute of Pharmacy and Food, University of Havana. Coronela, Lisa, Habana 13600, Cuba \\ ${ }^{5}$ Center for Research and Biological Evaluations, Institute of Pharmaceutical and Foods Sciences, University of Havana. Av. 23 \# 2317 b/214 and 222 , \\ La Coronela, La Lisa, Havana 13600, Cuba \\ ${ }^{6}$ Faculty of Exact, Natural and Agricultural Sciences, University of Santander (UDES). Bucaramanga, Santander, Colombia
}

Manuscript received: 19 August 2020. Revision accepted: 23 September 2020.

\begin{abstract}
Sarmiento-Tomalá GM, Miranda-Martínez M, Chóez-Guaranda IA, Gutiérrez-Gaitén YI, Delgado-Hernández, R, CarrilloLavid G. 2020. Pharmacognostic, chemical and mucolytic activity study of Malva pseudolavatera Webb \& Berthel. and Malva sylvestris L. (Malvaceae) leaf extracts, grown in Ecuador. Biodiversitas 21: 4755-4763. Among the cultivated and/or native plant species of Ecuador, are those belonging to Malvaceae. Of these, the most traditionally used are Malva pseudolavatera Webb \& Berthel. and Malva sylvestris L., which are grown and sold in indigenous markets. Various articles have been published for M. sylvestris about its chemical composition and pharmacological properties; however, M. pseudolavatera lacks references and is the most commercialized in Ecuador. Therefore, this work sets the following objective: To carry out a comparative study of the pharmacognostic, chemical and mucolytic activity of the species $M$. pseudolavatera and M. sylvestris. The species studied were collected in the province of Chimborazo. Extracts were obtained with different solvents: water, hexane and $80 \%$ ethanol. The aqueous extract was used to determine the mucolytic activity; the hexane and alcoholic extracts were analyzed by the coupled gas chromatography-mass spectrometry system. It was found that $M$. pseudolavatera has a very similar chemical composition to $M$. sylvestris; The presence of fatty acids, di and triterpenoids, phytosterols and abundant amino acids was detected. Both species showed an important mucolytic effect, the activity of M. pseudolavatera being higher than the highest doses tested. These studies provide scientific data that allow demonstrating the high potentiality of extracts from the leaves of two Malva species as sources of plant material for possible research and development of phytotherapeutic products with mucolytic and gastroprotective activity in correspondence with their uses in traditional Ecuadorian herbal medicine.
\end{abstract}

Keywords: Chemical composition, gas chromatography-mass spectrometry, pharmacognosy, physicochemical parameters

\section{INTRODUCTION}

Among the 10 countries with the greatest biodiversity in the world, Ecuador is home to $10 \%$ of the flora existing on the planet, where 64 of every 100 Ecuadorian species grow in the Andes mountain range. This great diversity of Ecuadorian flora has been recognized and studied, documenting the presence of more than 16,000 species of plants, although it is estimated that they exceed 20,000. Among the diversity of flora found in the country, many are considered medicinal due to their effects. Pharmacological attributes attributed to traditional medicine and the uses are given to it by the Andean communities (de la Torre et al. 2008). Among these species, those belonging to the genus Malva stand out, which includes some 30 species distributed in temperate, subtropical, and tropical zones of Africa, Asia, and Europe and has been introduced throughout the American continent (Gimeno 2000).
Many species of the genus are traditionally used for their medicinal use, but among them, Malva sylvestris stands out for its use as medicinal and consumption as food (Razavi et al. 2011; Gasparetto et al. 2012; Nasiri et al. 2015; Mofid et al. 2015). It is traditionally used in the treatment of skin conditions or damage due to its carminative, antimicrobial, and anti-inflammatory activities, in injuries and internal or external inflammation against edema, burns, helping to improve contraction and wound healing (Barros et al. 2010; Pardo et al. 2014; Saad et al. 2017; EMA/HMPC 2018). It is also attributed to mucolytic properties, such as a liver cleansing tonic (hepatoprotective), hypoglycemic, etc. (Prudente et al. 2013; Matera et al. 2015; Lim 2016). It is also used as food, in certain places in the Mediterranean region and in the form of infusions or herbal teas (Hussain et al. 2014; Ahmad et al. 2016; Jabri et al. 2017). 
Several chemical components have been reported for $M$. sylvestris, with the use of high-performance liquid chromatography, the presence of amino acids was detected including alanine, threonine, hydroxyproline, serine, glutamine, asparagine and arginine, trigonelline and glycine, as well as betaine in the leaves, flowers, and roots, respectively (Blunden et al. 2001). The presence of anthocyanosides, vitamins A, B1, B2, C, carotenes, coumarinic, chlorogenic and caffeic acids has also been reported, flavonoids, tannins, anthraquinone derivatives, and oleic, palmitic and stearic acids (Hiçsönmez et al. 2009; Zohra et al. 2013). The flowers and leaves contain mucilages (greater than $10 \%$ ) that by hydrolysis provide arabinose, glucose, rhamnose and galacturonic acid. In addition, the presence of terpenoids such as: sesquiterpenes, diterpenes, and monoterpenes has been reported (Classen and Blaschek 2002; Dipak 2016).

Among the species that are marketed in Ecuador, the one with the highest consumption is Malva pseudolavatera (de la Torre et al. 2008), however, so far there is no information on its chemical composition and biological properties, so the proposed objective of present work is to carry out a comparative study of the pharmacognostic, chemical and mucolytic activity of the species $M$. pseudolavatera and M. sylvestris.

\section{MATERIALS AND METHODS}

\section{Collection and drying}

The plant material (leaves of $M$. sylvestris and $M$. pseudolavatera), were collected in the month of September 2019 from the city of Riobamba $\left(1^{\circ} 40^{\prime} 15.5^{\prime \prime} \mathrm{S}\right.$, $\left.78^{\circ} 38^{\prime} 49.6^{\prime \prime W}\right)$, Chimborazo province, located in the Andes mountains at 2750 meters above sea level, having average area temperature of $13^{\circ} \mathrm{C}$, average humidity $62 \%$ and $561 \mathrm{~mm}$ annual precipitation

A sample of each species was herborized in the GUAY herbarium of the Faculty of Natural Sciences of the University of Guayaquil, Ecuador, where the herbarium numbers were assigned, 13118 M. sylvestris and 13119 M. pseudolavatera. Genetic characterization was also carried out on these species (Sarmiento-Tomalá et al. 2020).

The leaves of both species were washed with drinking water and dried in a Mettler Toledo brand oven at $40^{\circ} \mathrm{C}$, until constant weight, after which they were crushed in a Pulvex mill with blades at a particle size of $2 \mathrm{~mm}$ and stored in amber glass flasks.

\section{Determination of the physicochemical parameters of drugs: Qualitative chemical study}

The powder from the leaves of the two species were determined in triplicate and the physicochemical parameters, residual moisture (azeotropic method), content of soluble substances (water and hydroalcoholic mixtures at 30, 50, 80 , and 98\%), total ash, ash soluble in water and ashes insoluble in $10 \%$ hydrochloric acid were measured through the procedures described by WHO (2011). Phytochemical screening was performed on dry tubers, according to the procedure described by Miranda and Cuéllar (2000). An extraction system was used with a battery of solvents, of increasing polarity with ethyl ether, ethanol, and water, on the same plant material to obtain the corresponding extracts which were subjected to the different tests.

\section{Obtaining and analyzing extracts}

Three types of extracts were obtained: aqueous, hexane, and hydroalcoholic. The aqueous extract was prepared from $100 \mathrm{~g}$ of dry leaves crushed in $500 \mathrm{~mL}$ of distilled water. The mucilage was obtained by assisted precipitation, adding three volumes of $96 \%$ ethanol per $100 \mathrm{~mL}$ of the aqueous extract. Once filtered, the precipitate obtained was dehydrated at $50^{\circ} \mathrm{C}$ for 3 hours in a recirculating air oven (Vargas-Rodríguez et al. 2016).

The extraction with hexane was carried out by Soxhlet. Hexane (Merck) was used and an extraction time of two hours. $20 \mathrm{~g}$ of leaves of each species and $200 \mathrm{~mL}$ of hexane started and 3 extractions were made.; Subsequently, they were distilled in a Heildoph Laboratory model 4001 efficient $\mathrm{HB}$ digital rotary evaporator at reduced pressure, $50 \mathrm{rpm}$, and a temperature of $40^{\circ} \mathrm{C}$. The ethanolic extracts were made from the plant material at a rate of $20 \mathrm{~g}$ of drug/100 mL of solvent, by the maceration method with sporadic stirring, for a period of seven days at a temperature of $30^{\circ} \mathrm{C} \pm 2^{\circ} \mathrm{C}$, using an $80 \%$ hydroalcoholic mixture as solvent (Miranda and Cuéllar 2000).

Quality determinations were made on these extracts, three replicates for each experiment, the following parameters being evaluated: organoleptic properties (odor and color), $\mathrm{pH}$, refractive index (ABBE digital refractometer), relative density (by pycnometer), and solids total (Miranda and Cuéllar 2000). These extracts were also determined the content of total phenols by the FolinCiocalteu method (Pourmorad et al. 2006; Memnune et al. 2009; Chlopicka et al. 2012) and total flavonoids by the colorimetric method of aluminum chloride (Chang et al. 2002; Pourmorad et al. 2006).

\section{Saponification of the hexane extract and methylation of fatty acids}

The oils obtained from the hexane extract were independently saponified according to the technique of Bombón and Albuja (2014). Sodium hydroxide, concentrated hydrochloric acid, anhydrous sodium sulfate (Sigma-Aldrich), ethanol, and diethyl ether (Merck) were used. For the methylation of the fatty acids, a methanol/oil molar ratio of 11.66: 1 was used. The mixture was stirred at a temperature of $35^{\circ} \mathrm{C}$ for 3 minutes (Salimon et al. 2014).

\section{Analysis by gas chromatography-mass spectrometry}

The fractions of the methylated saponifiable compounds and the unsaponifiable ones were analyzed in an Agilent 7890A gas chromatograph coupled to an Agilent 5975C mass spectrometer with electron impact ionization source and simple quadrupole analyzer. Injector temperature: $280^{\circ}$ $\mathrm{C}$, injection volume $2 \mu \mathrm{L}$, helium carrier gas at $1 \mathrm{~mL} / \mathrm{min}$. The working conditions were: HP-5 column, 5\% Phenyl Methyl Siloxan of $30 \mathrm{~m} \times 0.30 \mathrm{~mm} \times 0.25 \mu \mathrm{m}$, initial temperature: $150^{\circ} \mathrm{C}$ for 4 minutes increasing $2^{\circ} \mathrm{C} / \mathrm{min}$ up to $300^{\circ} \mathrm{C}$ for $2 \mathrm{~min}$. Analysis time: $79 \mathrm{~min}$. 
Mass spectrometer operated at $70 \mathrm{eV}$ in full scan mode from 50 to 600 mass units. Source temperature $230^{\circ} \mathrm{C}$, quadrupole temperature $150^{\circ} \mathrm{C}$. Compounds were identified by comparing their mass spectra and the Wiley 9th mass reference with the NIST 2011 MS Library taking into account those with a percentage similarity of $95 \%$ or higher.

Extract ethanolic: Dried samples were mixed with $\mathrm{N}$, O-Bis (trimethylsilyl) trifluoroacetamide (BSTFA) and heated in a water bath at $80^{\circ} \mathrm{C}$ for $2 \mathrm{~h}$ to allow the silylation of metabolites (Saitta et al. 2002). Next, Gas Chromatography-Mass Spectrometry (GC-MS) analysis was performed in GC-MS equipment of the brand Agilent Technologies (7890A GC system and 5975C inert XL MSD with triple-axis detector). A capillary column DB5MS $(30 \mathrm{~m} \times 0.25 \mathrm{~mm})$ with phenyl dimethylpolysiloxane was used as stationary phase (0.25-micron film thickness) and helium as the carrier gas $(1.2 \mathrm{~mL} / \mathrm{min})$. The injection of $1 \mu \mathrm{L}$ of derivatized sample was performed at $250^{\circ} \mathrm{C}$ with splitless mode. The oven temperature was started at $70^{\circ} \mathrm{C}$ for 2 minutes, then it was increased to $300^{\circ} \mathrm{C}$ at $5^{\circ} \mathrm{C} / \mathrm{min}$, and it was maintained at $300^{\circ} \mathrm{C}$ for 6 minutes. The compounds identification was done by comparison of mass spectra based on the ninth version of the Wiley software, and NIST 2011 MS Library. An electron ionization of $70 \mathrm{eV}$ at $230^{\circ} \mathrm{C}$ was used in the ion source and the data compounds were collected with the full scan mode (40-600 amu) in the quadrupole mass analyzer.

\section{Mucolytic activity}

The precipitate of the aqueous extracts of $M$. sylvestris and M. pseudolavatera (mucilage) and the phenol red method (Engler and Szelenyi 1984) were used. 8 test groups were formed with 5 male mice each, of the CD1 strain with a weight between 25 and $30 \mathrm{~g}$, identified with letters from $\mathrm{A}$ to $\mathrm{H}$ at the different concentrations tested (Table 1). The administration of the precipitates and bromohexine was carried out orally and phenol red intraperitoneally.

After 24 hours of animal fasting, the administration of the $300 \mathrm{mg} / \mathrm{kg}$ phenol red indicator was administered to all groups of animals by the intraperitoneal route, except for the control group (-). 1 hour after the administration of phenol red, all groups of animals were sacrificed, followed by the removal of their tracheas, for their respective evaluation. All the animals used received care and attention according to the established international regulations, following Bioethics and Biosafety Standards established by (The World Medical Association 2016).

Table 1. Test groups for mucolytic activity

\begin{tabular}{ll}
\hline Groups & Description \\
\hline $\mathrm{A}$ & Control (-) Phenol red $300 \mathrm{mg} / \mathrm{kg} \mathrm{(bw)}$ \\
$\mathrm{B}$ & Control (+) Bromhexine $100 \mathrm{mg} / \mathrm{kg} \mathrm{(bw)}$ \\
$\mathrm{C}$ & Malva pseudolavatera $250 \mathrm{mg} / \mathrm{kg}(\mathrm{bw})$ \\
$\mathrm{D}$ & Malva pseudolavatera $500 \mathrm{mg} / \mathrm{kg}(\mathrm{bw})$ \\
$\mathrm{E}$ & Malva pseudolavatera $1000 \mathrm{mg} / \mathrm{kg} \mathrm{(bw)}$ \\
$\mathrm{F}$ & Malva sylvestris $250 \mathrm{mg} / \mathrm{kg} \mathrm{(bw)}$ \\
$\mathrm{G}$ & Malva sylvestris $500 \mathrm{mg} / \mathrm{kg} \mathrm{(bw)}$ \\
$\mathrm{H}$ & Malva sylvestris $1000 \mathrm{mg} / \mathrm{kg} \mathrm{(bw)}$ \\
\hline Note: bw: body weight
\end{tabular}

The phenol red concentration was determined spectrophotometrically (Genesys 10S UV VIS Spectrophotometer), using a wavelength of $546 \mathrm{~nm}$. For the determination, a blank composed of $1 \mathrm{~mL}$ of $0.9 \%$ sodium chloride and $0.1 \mathrm{~mL}$ of $0.1 \mathrm{~N} \mathrm{NaOH}$ solution was used. The percentages of mucolytic activity were determined by the following formula:

$\mathbf{P}=\frac{\mathbf{T}-\mathbf{C}}{\mathbf{C}} \times \mathbf{1 0 0}$

Where:

$\mathrm{P}$ : Percentage (\%) of mucolytic activity.

$\mathrm{T}$ : Tracheal secretion of phenol red in mice treated with the extracts every day.

C : Average tracheal secretion of phenol red in the group treated as control.

\section{Statistical analysis.}

Data were expressed as arithmetic mean/standard deviation. The one-way analysis of variance (One-way ANOVA) was used to determine if there was a statistically significant difference for the evaluated variable and then Kruskal-Wallis was applied, followed by the Friedman test. The level of significance set was $\mathrm{P}<0.05$. The data obtained in each trial were processed using the SPSS statistical package for Windows version 8.0.

\section{RESULTS AND DISCUSSION}

\section{Physicochemical parameters to drugs: Qualitative chemical study.}

The moisture content was within the range established by the literature for medicinal plants (8-14\%), although significant differences were observed between both species, with $M$. pseudolavatera presenting higher moisture content, which may be in correspondence with the dimensions of the leaves that are superior in this species. Of the solvents tested for the determination of extractable substances, the highest extractive power was achieved with water and the $50 \%$ hydroalcoholic mixture, which indicates a high concentration of polar substances.

Regarding ash, some Pharmacopoeias suggest a total ash index of up to 5\% (Lou 1980; WHO 2011) and another, such as the Chinese Pharmacopoeia (ChP 2015), refers up to $15 \%$. In the experience carried out, the percentage was found below the maximum allowed limit. On the other hand, the ashes insoluble in acid and soluble in water were higher than 2\%. Between both species, significant differences were found in this parameter (Table 2).

For the species $M$. sylvestris, it has been reported that it has the property of accumulating nutrients such as phosphorus, potassium, nitrogen, and magnesium, as well as heavy metals such as cadmium, copper, nickel, lead, and zinc (Elsagh et al. 2015; Ahmad et al. 2016), which may justify the high values found for ash.

In the phytochemical analysis, there were no differences in the chemical composition of the drugs under study. The presence of phenolic compounds, triterpenes/ steroids, and mucilage should be highlighted (Table 3). 
Table 2. Physicochemical parameters of raw drugs from Malva sylvestris and M. pseudolavatera leaves

\begin{tabular}{|c|c|c|}
\hline \multirow{2}{*}{ Parameters (\%) } & \multicolumn{2}{|c|}{ Results ( $\overline{\mathbf{x}} / \mathbf{S D})$} \\
\hline & M. silvestris & M. pseudolavatera \\
\hline Moisture content (\%) & $873 / 013^{\mathrm{a}}$ & $1014 / 014^{\mathrm{b}}$ \\
\hline Water-soluble extractive & $3045 / 119^{c}$ & $2738 / 101^{\mathrm{d}}$ \\
\hline Alcohol-soluble extractive at $30 \%$ & $1877 / 149^{\mathrm{e}}$ & $1951 / 059^{\mathrm{e}}$ \\
\hline Alcohol-soluble extractive at $50 \%$ & $2305 / 026^{\mathrm{f}}$ & $1710 / 010^{g}$ \\
\hline Alcohol-soluble extractive at $80 \%$ & $1579 / 023^{\mathrm{h}}$ & $1092 / 032^{\mathrm{i}}$ \\
\hline Alcohol-soluble extractive at $98 \%$ & $1006 / 013^{j}$ & $739 / 033^{\mathrm{k}}$ \\
\hline Total ash content & $1424 / 032^{1}$ & $1525 / 014^{\mathrm{m}}$ \\
\hline Water-soluble ash & $435 / 02^{\mathrm{n}}$ & $417 / 006^{\mathrm{n}}$ \\
\hline Acid-insoluble ash & $1261 / 017^{\circ}$ & $1302 / 008^{p}$ \\
\hline
\end{tabular}

Note: $\overline{\mathrm{x}} / \mathrm{SD}$ : Average value of determinations $(\mathrm{n}=3) /$ standard deviation. Different letters in a row show significant differences $(\mathrm{p}<0.05)$

Table 3. Phytochemical screening of raw drugs from Malva sylvestris and M. pseudolavatera

\begin{tabular}{|c|c|c|c|c|c|c|c|}
\hline \multirow{3}{*}{ Metabolites } & \multirow{3}{*}{ Name of test } & \multicolumn{6}{|c|}{ Extracts } \\
\hline & & \multicolumn{2}{|c|}{ Ethereal } & \multicolumn{2}{|c|}{ Alcoholic } & \multicolumn{2}{|c|}{ Aqueous } \\
\hline & & MS & MP & MS & MP & MS & MP \\
\hline Fats or oil & Sudan III & + & + & & & & \\
\hline Mucilages & Mucilage test & & & & & ++ & ++ \\
\hline Coumarins/lactones & Baljet test & - & - & + & - & & \\
\hline Triterpenes/steroids & Liebermann- & ++ & ++ & ++ & ++ & & \\
\hline & Burchard & Green dark & Green dark & Green dark & Reddish green dark & & \\
\hline Saponins & Foam test & & & + & + & \pm & \pm \\
\hline Resins & Resin test & & & - & - & & \\
\hline Amino acids & Ninhydrin & & & ++ & ++ & & \\
\hline Reducing compounds & Fehling test & & & ++ & ++ & ++ & ++ \\
\hline Phenols/tannins & Ferric chloride test & & & ++ & ++ & ++ & + \\
\hline Anthocyanins & $\mathrm{HCl}$ conc./pentanol & & & ++ & ++ & & \\
\hline & & & & Brown & Brown & & \\
\hline Quinones & Börntrager & & & + & + & & \\
\hline Flavonoids & Shinoda $(\mathrm{Mg}-\mathrm{HCl})$ & & & ++ & ++ & ++ & ++ \\
\hline & & & & Brown & Brown & Yellow & Yellow \\
\hline Cardiac glycosides & Kedde test & & & - & - & & \\
\hline Catechins & Catechin test & & & + & + & & \\
\hline Bitter \& astringent principles & & & & & & + & + \\
\hline
\end{tabular}

Note: + : positive, ++ : Highly positive, - : negative, \pm : undefined test, MS: Malva sylvestris, MP: Malva pseudolavatera

\section{Analysis of the extracts}

To the hydroalcoholic extracts of the species under study, the quality parameters were determined (Table 4), for the parameters $\mathrm{pH}$ and total solid significant differences ( $p<0.05$ ) were found between the species. For M. sylvestris the $\mathrm{pH}$ value was closer to neutral values, while for $M$. pseudolavatera the $\mathrm{pH}$ was close to acid values. On the other hand, total solids were somewhat higher for $M$. sylvestris.

The content of total phenols was determined by the Folin-Ciocalteu method, in the quantification of total flavonoids the colorimetric method of aluminum chloride was used. In both quantifications, calibration curves with good correlation between the tested concentrations of the reference substances (gallic acid and quercetin) and the absorbances were achieved. The correlation coefficient $\left(R^{2}\right)$ was $\geq 0.99$, this is indicative of the good fit of the model equation to the experimental data (Figure 1).
Table 5 shows that the species $M$. sylvestris presented a higher content of phenols and total flavonoids with significant differences between them. Phenolic compounds and flavonoids in particular are associated with a wide spectrum of health benefits, which is due to the wide range of pharmacological properties, associated with their ability to modulate the key functions of many cellular enzymes (Panche et al. 2016; Najjaa et al. 2020). The concentration of these metabolites in plants is very sensitive to environmental and climatic conditions, geographical location, and taxonomic variety (Najjaa et al. 2020).

\section{Analysis by gas chromatography-mass spectrometry} Fractions of saponifiable and unsaponifiable compounds

As can be seen in Figure 2 and Table 6, for the fraction of saponifiable compounds, three fatty acids were identified, the majority being linolenic acid. These three compounds presented higher abundance for the species $M$. pseudolavatera and have been reported for the species $M$. sylvestris (Mofid et al. 2015). 
Table 4. Physicochemical parameters of the hydroalcoholic extracts from Malva sylvestris and M. pseudolavatera

\begin{tabular}{lll}
\hline \multirow{2}{*}{ Parameters (\%) } & \multicolumn{2}{c}{ Results $(\overline{\mathbf{x}} /$ SD) } \\
\cline { 2 - 3 } \multicolumn{1}{c}{ pH } & \multicolumn{1}{c}{ M. sylvestris } & \multicolumn{1}{c}{ M.pseudolavatera } \\
Total solids (\%) & $6.20 / 0.01^{\mathrm{a}}$ & $5.83 / 0.02^{\mathrm{b}}$ \\
Refraction index & $1.88 / 0.09^{\mathrm{c}}$ & $1.40 / 0.05^{\mathrm{d}}$ \\
Relative density (mg/mL) & $1.3601 / 0.0001^{\mathrm{e}}$ & $1.3593 / 0.0002^{\mathrm{f}}$ \\
\hline
\end{tabular}

Note: $\bar{x} / \mathrm{SD}=$ Average value of determinations $(\mathrm{n}=3) /$ standard deviation. Different letters in a row show significant differences $(\mathrm{p}<0.05)$

In the unsaponifiable compound fractions, 10 components were identified for each species (Figure 3, Table 6). For both fractions, an abundance of hydrocarbons is observed, the majority of them being nonacosane for the species $M$. pseudolavatera and triclosan for M. sylvestris. With the exception of nonacosane, the rest of the hydrocarbons presented a higher percentage of abundance in M. sylvestris. Hydrocarbons are part of plant waxes that are modifications of the cell wall by deposit and serve as protection against excessive evaporation of water (Miranda and Cuéllar 2012).

The diterpenoids neophytadiene and phytol, the acyclic triterpenoid squalene, and the sterol stigmasterol were also found in these extracts, all with greater abundance in $M$. pseudolavatera and stigmasterol not detected in the $M$. sylvestris species, possibly due to concentration problems. Terpenoids have also been reported metabolites for the species $M$. sylvestris, linked to different pharmacological activities (Mohajer et al. 2016).
Table 5. Total phenols and total flavonoids content of the hydroalcoholic extracts from Malva sylvestris and $M$. pseudolavatera

\begin{tabular}{lcc}
\hline \multicolumn{1}{c}{ Extracts } & $\begin{array}{c}\text { Total phenols } \\
(\mathbf{m m g} / \mathbf{m L}) \\
\overline{\mathbf{x}} / \mathbf{S D}\end{array}$ & $\begin{array}{c}\text { Total flavonoids } \\
(\mathbf{m m g} / \mathbf{m L}) \\
\overline{\mathbf{x}} / \mathbf{S D}\end{array}$ \\
\hline M. sylvestris & $1.88 / 0.03^{\mathrm{a}}$ & $1.65 / 0.02^{\mathrm{c}}$ \\
M. pseudolavatera & $1.47 / 0.04^{\mathrm{b}}$ & $1.22 / 0.01^{\mathrm{d}}$ \\
\hline
\end{tabular}

Note: $\bar{x} / \mathrm{SD}=$ Average value of determinations $(n=3) /$ standard deviation. Different letters in a row show significant differences $(\mathrm{p}<0.05)$

\section{Hydroalcoholic extracts}

Figure 4 shows the analytical gas chromatograms of the hydroalcoholic extracts of the two species under study. Great complexity is observed in both extracts with appreciable qualitative differences. Table 7 shows the compounds identified for both extracts.

For the species $M$. sylvestris, the major component was $\alpha$-linolenic acid $(30.61 \%)$, followed by palmitic acid $(12.14 \%)$ and stearic acid $(8.31 \%)$. For the species $M$. pseudolavatera, the main component was glucitol sugar (14.91\%), although the fatty acids $\alpha$-linolenic acid (13.75\%), palmitic acid $(13.40 \%)$, and stearic acid (14.98\%) were also present with different abundance percentages.

An important aspect to highlight is that in addition to fatty acids and sugars, the presence of abundant amino acids in both extracts and some triterpenes and sterols were detected, all these compounds previously reported for $M$. sylvestris (EMA/HMPC 2018).

The differences that are qualitatively observed may be due to concentration problems not detectable by the equipment or to biogenetic differences between species.

Table 6. Compounds identified in the fractions of saponifiable and unsaponifiable compounds of Malva sylvestris and M. pseudolavatera

\begin{tabular}{|c|c|c|c|c|c|c|}
\hline No. & $\begin{array}{c}\text { RT } \\
(\mathbf{m i n})\end{array}$ & Compound & $\begin{array}{c}\text { Content \% } \\
\overline{\mathbf{x}} / \mathrm{SD}\end{array}$ & $\begin{array}{c}\text { RT } \\
(\mathbf{m i n})\end{array}$ & Compound & $\begin{array}{c}\text { Content \% } \\
\overline{\mathbf{x}} / \mathrm{SD}\end{array}$ \\
\hline & & \multicolumn{3}{|l|}{ M. sylvestris } & \multicolumn{2}{|l|}{ M. pseudolavatera } \\
\hline & & \multicolumn{5}{|l|}{ Saponifiable fraction } \\
\hline 1 & 20.07 & Hexadecanoic acid (palmitic acid) & 23.17/1.64 & 20.08 & Hexadecanoic acid (palmitic acid) & $27.42 / 7.65$ \\
\hline 2 & 26.95 & 9,12-octadecadienoic acid (linoleic acid) & $6.81 / 0.49$ & 26.96 & 9,12-octadecadienoic acid (linoleic acid) & $11.02 / 3.46$ \\
\hline 3 & 27.16 & $\begin{array}{l}9,12,15 \text {-octadecatrienoic acid (linolenic } \\
\text { acid) }\end{array}$ & $35.46 / 3.03$ & 27.17 & $\begin{array}{l}9,12,15 \text {-octadecatrienoic acid (linolenic } \\
\text { acid) }\end{array}$ & $61.56 / 6.75$ \\
\hline & & \multicolumn{5}{|l|}{ Unapponable fraction } \\
\hline 1 & 26.17 & neophytadiene & $4.80 / 0.06$ & 26.17 & neophytadiene & $5.00 / 0.20$ \\
\hline 2 & 31.42 & phytol & $7.12 / 0.12$ & 31.43 & phytol & $26.95 / 0.63$ \\
\hline 3 & 32.60 & docosane & $0.50 / 0.01$ & & & \\
\hline 4 & 34.84 & tricosane & $35.85 / 0.25$ & 34.82 & tricosane & $4.81 / 0.13$ \\
\hline 5 & 36.47 & tetracosane & $1.73 / 0.01$ & 36.47 & tetracosane & $0.44 / 0.02$ \\
\hline 6 & 38.06 & pentacosane & $11.28 / 0.06$ & 38.06 & pentacosane & $3.59 / 0.11$ \\
\hline 7 & 41.07 & heptacosane & $16.33 / 0.02$ & 41.06 & heptacosane & $9.66 / 0.36$ \\
\hline 8 & 42.48 & octacosane & $1.41 / 0.08$ & 42.48 & octacosane & $2.97 / 0.03$ \\
\hline 9 & 42.62 & squalene & $1.49 / 0.05$ & 42.60 & squalene & $1.62 / 0.10$ \\
\hline 10 & 43.86 & nonacosane & $19.49 / 0.07$ & 43.88 & nonacosane & $42.99 / 1.17$ \\
\hline 11 & . & & & 48.96 & 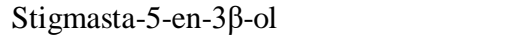 & $1.98 / 0.22$ \\
\hline
\end{tabular}

Note: $\overline{\mathrm{x}} / \mathrm{SD}=$ Average value of determinations/standard deviation $(\mathrm{n}=3)$ 
Table 7. Compounds identified in the hydroalcoholic extracts of Malva sylvestris and M. pseudolavatera

\begin{tabular}{|c|c|c|c|c|c|c|}
\hline No. & $\begin{array}{c}\text { RT } \\
(\mathbf{m i n})\end{array}$ & Compound & $\begin{array}{c}\text { Content \% } \\
\overline{\mathbf{x}} / \mathrm{SD}\end{array}$ & $\begin{array}{c}\text { RT } \\
(\mathbf{m i n})\end{array}$ & Compound & $\begin{array}{c}\text { Content \% } \\
\overline{\mathbf{x}} / \mathrm{SD}\end{array}$ \\
\hline & & $\begin{array}{c}\text { Hydroalcoholic extracts } \\
\text { M. sylvestris } \\
\end{array}$ & & & $\begin{array}{l}\text { Hydroalcoholic extracts } \\
\text { M. pseudolavatera }\end{array}$ & \\
\hline 1 & 8.32 & L-alanine & $5.26 / 0.03$ & & & \\
\hline 2 & 11.22 & L-valine & $1.48 / 0.01$ & 11.20 & L-valine & $4.47 / 0.02$ \\
\hline 3 & & & & 13.00 & Nicotinic acid & $0.27 / 0.04$ \\
\hline 4 & 13.91 & Butanedioic acid, Succinic acid & $1.39 / 0.16$ & 13.65 & Butanedioic acid, Succinic acid & $1.65 / 0.07$ \\
\hline 5 & & & & 14.42 & Uracil & $0.41 / 0.06$ \\
\hline 6 & & & & 14.87 & 2-butenedioic acid, Fumaric acid & $2.41 / 0.35$ \\
\hline 7 & & & & 15.75 & L-threonine & $1.92 / 0.28$ \\
\hline 8 & 19.15 & L-aspartic acid & $7.16 / 0.03$ & 19.12 & L-aspartic acid & $2.61 / 0.38$ \\
\hline 9 & 19.97 & L-threonic acid & $1.43 / 0.08$ & 19.68 & L-threonic acid & $1.92 / 0.28$ \\
\hline 10 & & & & 22.03 & L-arabinopyranose & $0.76 / 0.11$ \\
\hline 11 & 23.41 & L-lysine & $1.02 / 0.01$ & 23.41 & L-lysine & $1.00 / 0.15$ \\
\hline 12 & 25.80 & Citric acid & $0.69 / 0.03$ & 25.78 & Citric acid & $0.89 / 0.13$ \\
\hline 13 & 26.60 & Adenine & $1.75 / 0.02$ & 26.60 & Adenine & $2.61 / 0.35$ \\
\hline 14 & 28.02 & Glucitol & $2.31 / 0.01$ & 28.03 & Glucitol & $14.91 / 0.04$ \\
\hline 15 & 28.15 & L-tyrosine & $4.80 / 0.01$ & & & \\
\hline 16 & 29.30 & Hexadecanoic acid ethyl ester & $1.66 / 0.00$ & 29.29 & Hexadecanoic acid ethyl ester & $1.72 / 0.00$ \\
\hline 17 & 29.65 & Purine & $3.14 / 0.04$ & & & \\
\hline 18 & 30.32 & Hexadecanoic acid & $12.14 / 0.05$ & 30.32 & Hexadecanoic acid & $13.40 / 0.02$ \\
\hline 19 & 31.61 & Guanina & $0.78 / 0.01$ & 31.61 & Guanina & $0.48 / 0.00$ \\
\hline 20 & 32.44 & $9,12,15$-octadecatrienoic acid ethyl ester & $3.74 / 0.01$ & 32.32 & $9,12,15$-octadecatrienoic acid ethyl ester & $3.55 / 0.00$ \\
\hline 21 & 33.16 & L-tryptophan & $6.60 / 0.00$ & 33.16 & L-tryptophan & $9.42 / 0.03$ \\
\hline 22 & 33.23 & 9,12-octadecadienoic acid & $2.91 / 0.00$ & 33.22 & 9,12-octadecadienoic acid & $2.27 / 0.01$ \\
\hline 23 & 33.41 & A-linolenic acid & $30.61 / 0.08$ & 33.36 & A-linolenic acid & $13.75 / 0.04$ \\
\hline 24 & 33.46 & Oleic acid & $0.46 / 0.00$ & 33.45 & Oleic acid & $1.17 / 0.01$ \\
\hline 25 & 33.85 & Octadecanoic acid & $8.31 / 0.04$ & 33.86 & Octadecanoic acid & $14.98 / 0.03$ \\
\hline 26 & 49.23 & B-sitosterol & $1.34 / 0.01$ & 49.23 & B-sitosterol & $1.79 / 0.01$ \\
\hline 27 & & & & 49.49 & B-amyrin & $0.48 / 0.01$ \\
\hline 28 & 50.09 & A-amyrin & $1.02 / 0.00$ & 50.09 & A-amyrin & $0.62 / 0.01$ \\
\hline
\end{tabular}

Note: $\mathrm{RT}=$ retention time, $\overline{\mathrm{x}} / \mathrm{SD}=$ Average value of determinations/standard deviation $(\mathrm{n}=3)$

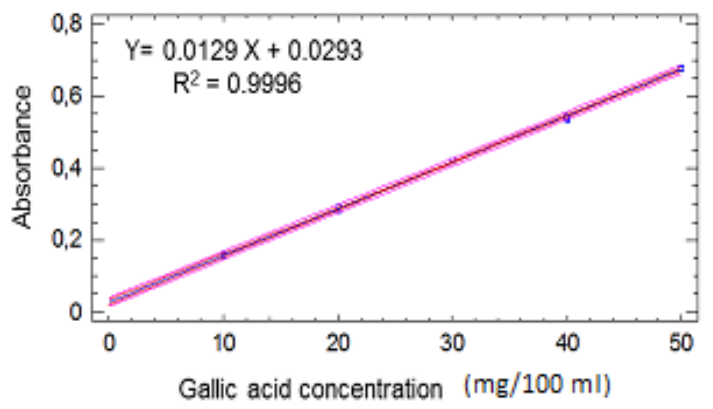

A

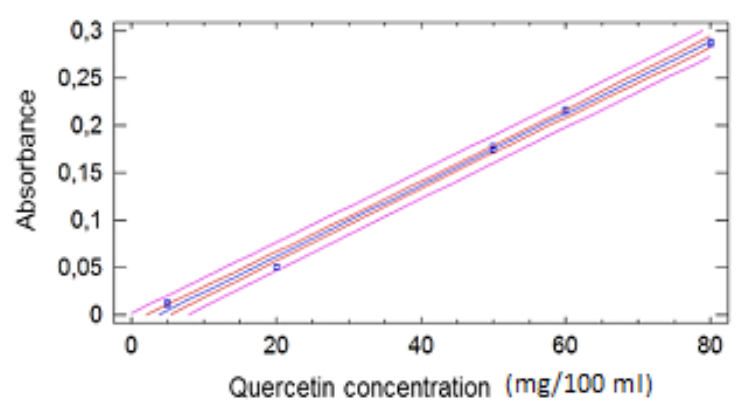

B

Figure 1. Calibration curves of the gallic acid (A) and quercetin (B) for the determination of total phenols and total flavonoids

\section{Mucolytic activity}

Mucolytic drugs change the biophysical properties of airway secretions, lowering their viscosity, preventing a large amount of phlegm that could obstruct airflow and ultimately lead to the development of respiratory diseases, such as bronchitis, asthma, and chronic obstructive pulmonary disease. Although a different approach to mucolytic medication has been investigated for decades, only a few mucolytic agents from medicinal plants have been defined (Wisastra and Arifin 2020). In this context, the mucolytic activity of $M$. sylvestris and $M$. pseudolavatera was evaluated using the Phenol Red method, since it is an indicator that has an adequate study of drugs that modify tracheobronchial secretions (Engler and Szelenyi 1984).

The results for the determination of mucolytic activity are illustrated in Figure 5. It is possible to show the highest percentages of activity in the higher doses, which indicates that there is a directly proportional relationship, doseresponse; the higher the dose, the greater the effect; presenting a better percentage of efficacy for both $M$. pseudolavatera and M. sylvestris in the doses of 500 and $1000 \mathrm{mg} / \mathrm{kg}$ against the reference drug bromhexine. 


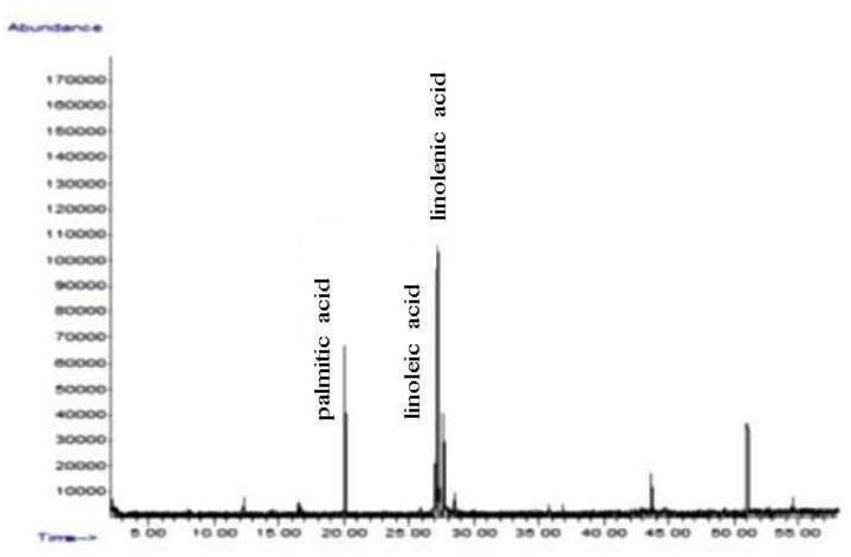

A

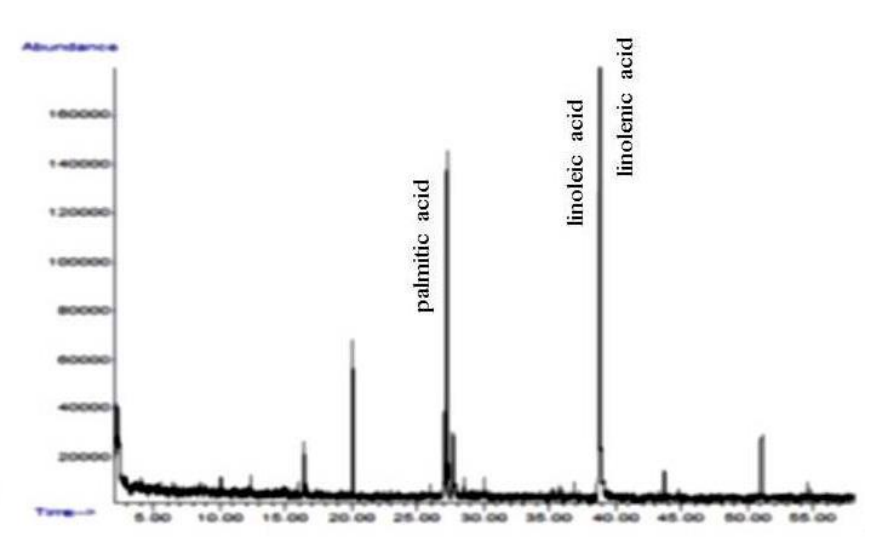

B

Figure 2. Analytical gas chromatogram of the fraction of saponifiable compounds of the leaves. A. Malva sylvestris and B. M. pseudolavatera
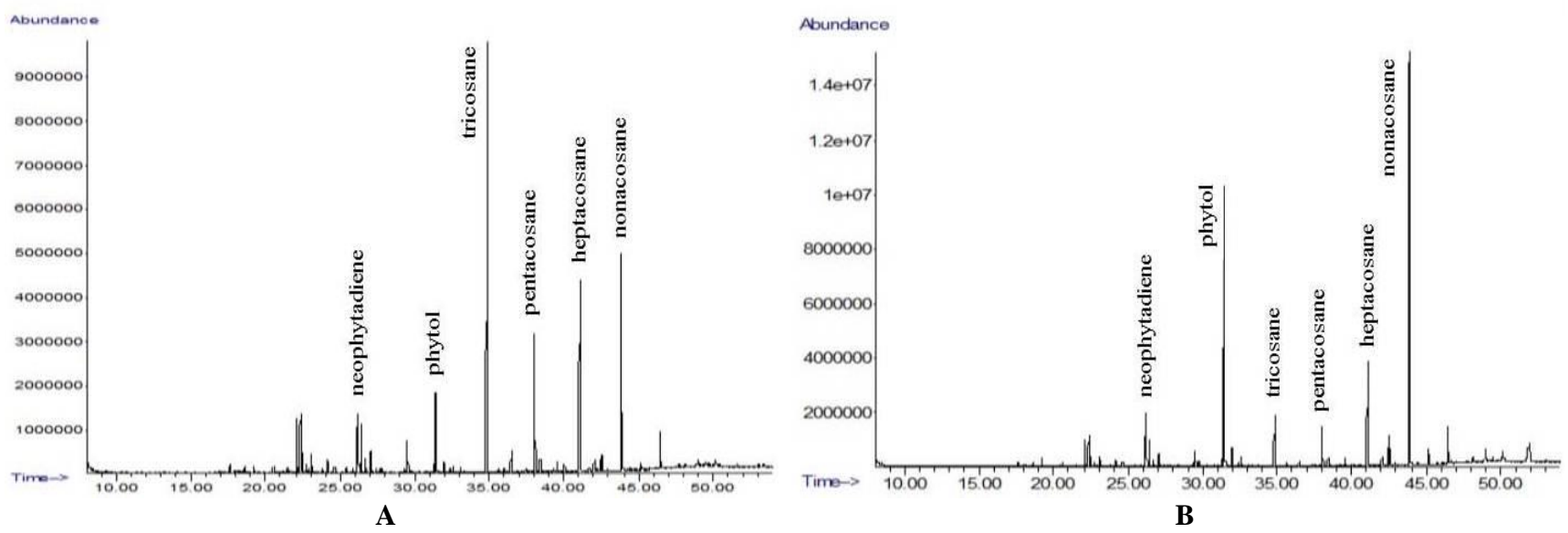

Figure 3. Analytical gas chromatogram of the fraction of unsaponifiable compounds of the leaves. A. Malva sylvestris and B. M. pseudolavatera

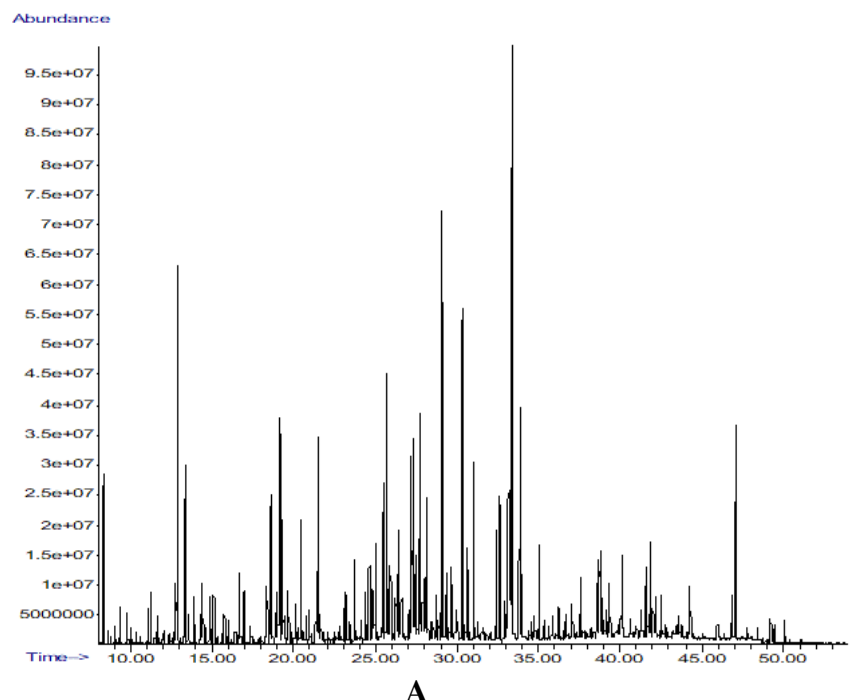

A

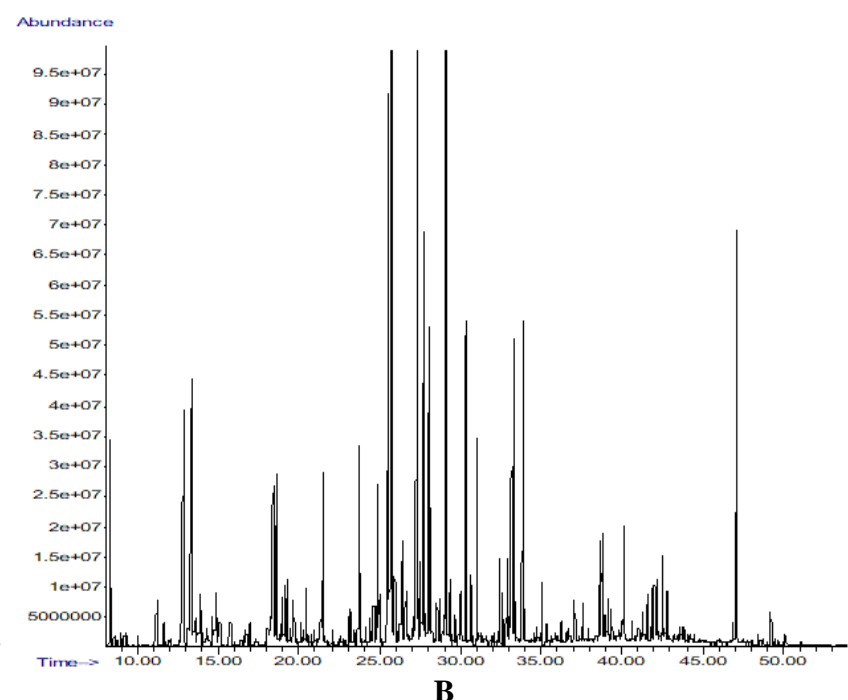

B

Figure 4. Analytical gas chromatogram of the hydroalcoholic extract of the leaves. A. Malva sylvestris and B. M. pseudolavatera 


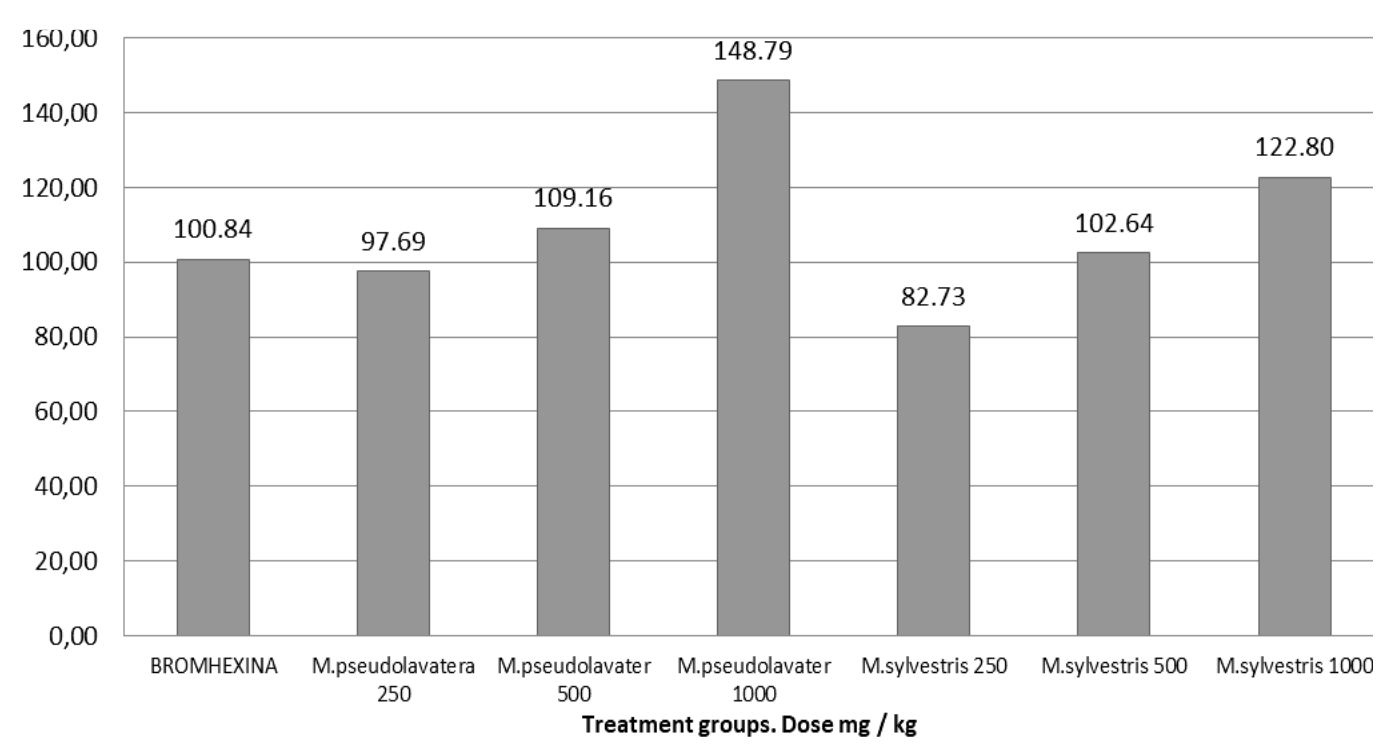

Figure 5. Percentages of mucolytic activity presented by the different groups tested

Bromhexine is a mucolytic agent with antioxidant properties that is used as a secretolytic expectorant for the effective treatment of cough with phlegm. The mechanism of action is based on the breakdown of phlegm, improves the production of serous mucus in the respiratory tract, and makes the phlegm less viscous. This contributes to a secretomotor effect by helping the cilia to expel phlegm out of the lungs (Bhagat and Rachana 2018). This activity was demonstrated when there was an increase in the concentration of phenol red in the tracheobronchial secretions of the experimental animals, which is reflected by the different absorbances.

\section{REFERENCES}

Adesina SK, Johnny II, Olayiwola G. 2017. Plants in respiratory disorders II antitussives, a review. $\mathrm{Br} \mathrm{J}$ Pharm Res 16: 1-21. DOI: 10.9734/BJPR/2017/32974.

Ahmad M, Khan MPZ, Mukhtar A, Zafar M, Sultana S, Jahan S. 2016 Ethnopharmacological survey on medicinal plants used in herbal drinks among the traditional communities of Pakistan. J Ethnopharmacol 184: 154-86. DOI: 10.1016/j.jep.2016.02.039.

Ameri A, Heydarirad G, Jafari MJ, Ghobadi A, Rezaeizadeh H, Choopani R. 2014. Medicinal plants contain mucilage used in traditional Persian medicine (TPM). Pharm Biol 53: 615-623. DOI: 10.3109/13880209.2014.928330.

Barros L, Carvalho AM, Ferreira ICFR. 2010. Leaves, flowers, immature fruits and leafy flowered stems of Malva sylvestris: a comparative study of the nutraceutical potential and composition. Food Chem Toxicol 48: 1466-1472. DOI: 10.1016/j.fct.2010.03.012.

Bhagat A, Rachana. 2018. Bromhexine: A Comprehensive Review. Int J Biol Med Res 9: 6455-6459.

Blunden G, Patel AV, Armstrong NJ, Gorham J. 2001. Betaine distribution in the Malvaceae. Phytochem 58: 451-454. DOI: $10.1016 / \mathrm{s} 0031-9422$.

Bombón N, Albuja M. 2014. Diseño de una planta de saponificación para el aprovechamiento del aceite vegetal de desecho. Rev Politéc 34: 22. [Spanish]
Carretero Accame ME, Ortega Hernández-Agero T. 2017. Plantas medicinales antitusivas. Panor actual del medicamen 41: 692-697. [Spanish]

Chang CC, Yang MH, Wen HM, Chern JC. 2002. Estimation of total flavonoid content in propolis by two complementary colorimetric methods. J Food Drug Anal 10: 178-182. DOI: 10.38212/22246614.2748 .

Chlopicka J, Pasko P, Gorinstein S, Jedryas A, Zagrodzki P. 2012. Total phenolic and total flavonoid content, antioxidant activity, and sensory evaluation of pseudocereal bread. LWT- Food Sci Technol 46: 548555. DOI: 10.1016/j.lwt.2011.11.009.

Classen B, Blaschek W. 2002. An arabinogalactan-protein from cell culture of Malva sylvestris. Planta Med 68: 232-236. DOI: 10.1055/s2002-23127.

ChP. 2015. Pharmacopoeia of the People's Republic of China. Vol. 1. Chinese Medical Science and Technology Press, Peking.

de la Torre L, Navarrete H, Muriel PM, Macía MJ, Balslev H. 2008. Enciclopedia de las Plantas Útiles del Ecuador. Herbario QCA \& Herbario AAU. Quito \& Aarhus, Quito..

Dipak P. 2016. A review on biological activities of common mallow (Malva sylvestris L.). Innovare J Life Sci 4: 1-5.

Elsagh M, Fartookzadeh MR, Kamalinejad M, Anushiravani M, Feizi A, Behbahani FA, Rafiei R, Arjmandpour A, Adibi P. 2015. Efficacy of the Malva sylvestris L. flowers aqueous extract for functional constipation: A placebo-controlled trial. Complement Ther Clin Pract 21: 105-11. DOI: 10.1016/j.ctcp.2015.02.003.

EMA/HMPC. 2018. Assessment report on Malva sylvestris L. and/or Malva neglecta Wallr., folium and Malva sylvestris L., flos. European Medicines Agency. London.

Engler H, Szelenyi I. 1984. Tracheal Phenol Red secretion, a new method for screening mucosecretolytic compounds. J Pharmacol Methods 11: 151-157. DOI: 10.1016/0160-5402(84)90033-0.

Gasparetto JC, Ferreira MCA, Hayashia SS, Fleith OM, Pontarolo R. 2012. Ethnobotanical and scientific aspects of Malva sylvestris L.: a millennial herbal medicine. J Pharm Pharmacol 64: 172-189. DOI: 10.1111/j.2042-7158.2011. 01383.x.

Gimeno Gasca JM. 2000. Malva (Malva sylvestris L.). Medicina Naturista 2: $109-111$.

Giombelli LF, Horn AC, Colacite J. 2012. Perfil fitoquímico e atividade antimicrobiana das folhas de Malva sylvestris (Malvaceae). Rev de Biol e Saúde da UNISEP. 5: 17-22. [Spanish]

Hiçsönmez Ü, Ereeş FS, Özdemir C, Özdemir A, Çam S. 2009. Determination of major and minor elements in the Malva sylvestris $\mathrm{L}$. from turkey using ICP-OES techniques. Biol Trace Elem Res 128: 248-257. DOI: 10.1007/s12011-008-8270-0. 
Hussain L, Ikram J, Rehman K, Tariq M, Ibrahim M, Akash MSH. 2014 Hepatoprotective effects of Malva sylvestris L. against paracetamolinduced hepatotoxicity. Turk J Biol 38: 396-402. DOI: 10.3906/biy1312-32.

Jabri M-A, Wannes D, Hajji N, Sakly M, Marzouki L, Sebai H. 2017. Role of laxative and antioxidant properties of Malva sylvestris leaves in constipation treatment. Biomed Pharmacother 89: 29-35. DOI: 10.1016/j.biopha.2017.02.020

Lim TK. 2015. Edible Medicinal and Non-Medicinal Plants, flowers. Springer Nature 9: 659.

Lou ZC. 1980. General control methods for vegetable drugs. Comparative study of methods included in thirteen pharmacopoeias a proposal on their international unification. WHO/PHARM/80. 502: 8-39.

Matera SI, Ragone MI, Consolini AE. 2015. Farmacología Experimental de Plantas Medicinales y Fitoterapia: Enseñanza del Método Científico a Estudiantes de Farmacia. In: IV Jornadas de Enseñanza e Investigación Educativa en el campo de las Ciencias Exactas y Naturales. Facultad de Humanidades y Ciencias de la Educación. Universidad Nacional de La Plata, La Plata. [Spanish]

Miranda MM, Cuéllar AC. 2012. Farmacognosia y Química de productos naturales, $2^{\text {nd }}$ Edition. Varela F (ed), La Habana, Cuba.

Miranda MM, Cuéllar AC. 2000. Manual de prácticas de laboratorio. Farmacognosia y productos naturales. Ciudad Habana. 25-49: 74-79. [Spanish]

Mofid B, Rezaeizadeh H, Jaladat AM, Atarzadeh F, Moeini R, Motevalian A, Mosalaie A, Farhan F, Rakhsha A, Kashi AS. 2015. Preventive effect of Malva on urinary toxicity after radiation therapy in prostate cancer patients: A multi-centric, double-blind, randomized clinical trial. Electron Physician 7: 1220-1226. DOI: 10.14661/1220.

Mohajer S, Taha RM, Ramli RB, Mohajer M. 2016. Phytochemical constituents and radical scavenging properties of Borago officinalis and Malva sylvestris. Ind Crops Prod 94: 673-681. DOI: $10.1016 /$ j.indcrop.2016.09.045.

Najjaa H, Abdelkarim BA, Doria E, Boubakri A, Trabelsi N, Falleh H, Tlili H, Neffati M. 2020. Phenolic composition of some Tunisian medicinal plants associated with anti-proliferative effect on human breast cancer MCF-7 cells. EuroBiotech J 4: 104-112. DOI: 10.2478/ebtj-2020-0012.

Nasiri E, Hosseinimehr SJ, Azadbakht M, Akbari J, Enayati-Fard R, Azizi S. 2015. Effect of Malva sylvestris cream on burn injury and wounds in rats. Avicenna J Phytomed 5: 341-354.

Moogahi N, Khanehzad M, Sadr M, Roholahi, Kameli. 2013 Comparative effects of Alcea sulphurea and Bromhexine HCL on mucociliary system of chicken trachea. J Med Plants 12: 54-61.

Panche AN, Diwan AD, Chandra SR. 2016. Flavonoids: an overview. J Nutr Sci 5:1-15. DOI: 10.1017/jns.2016.41.

Pardo de Santayana M, Morales R, Aceituno-Mata L, Molina M. 2014 (ed). Malva sylvestris L. In: Inventario Español de los Conocimientos Tradicionales relativos a la Biodiversidad. 1st ed. Madrid. Ministerio de Agricultura, Alimentación y Medio Ambiente, Madrid. [Spanish]

Pourmorad F, Hosseinimehr SJ, Shahabimajd N. 2006. Antioxidant activity, phenol and flavonoid contents of some selected Iranian medicinal plants. Afr J Biotechnol 5: 1142-1145.
Prudente AS, Loddi AMV, Duarte MR, Santos ARS, Pochapski MT, Pizzolatti MG, Hayashi SS, Campos FR, Pontarolo R, Santos FA, Cabrini DA, Otuki MF. 2013. Pre-clinical anti-inflammatory aspects of a cuisine and medicinal millennial herb: Malva sylvestris L. Food Chem Toxicol 58: 324-331. DOI: 10.1016/j.fct.2013.04.042.

Razavi SM, Zarrini G, Molavi G, Ghasemi G. 2011. Bioactivity of Malva sylvestris L., a medicinal plant from Iran. Iran J Basic Med Sci 14: 574-579.

Saad AB, Rjeibi I, Alimi H, Ncib S, Smida A, Zouari N, Zourgui L. 2017. Lithium induced, oxidative stress and related damages in testes and heart in male rats: The protective effects of Malva sylvestris extract. Biomed Pharmacother 86: 127-135. DOI: 10.1016/j.biopha.2016.12.004.

Saitta M, Curto SL, Lo Salvo F, Di Bella G, Dugo G. 2002. Gas chromatographic-tandem mass spectrometric identification of phenolic compounds in Sicilian olive oils. Anal Chim Acta 466: 335 344. DOI: 10.1016/S0003-2670(02)00572-X.

Salimon J, Omar TA, Salih N. 2014. Comparison of two derivation methods for the analysis of fatty acids and trans-fatty acids in bakery products using gas chromatography. Sci World J 906407: 1-10. DOI: 10.1155/2014/906407..

Sarmiento-Tomalá G, Santos-Ordóñez E, Miranda-Martínez M, PachecoCoello R, Scull-Lizama R, Gutiérrez-Gaitén Y, Delgado-Hernández R. 2020. Molecular barcode and morphology analysis of Malva pseudolavatera Webb \& Berthel and Malva sylvestris L. from Ecuador. Biodiversitas 21: 3554-3561. DOI: 10.13057/biodiv/d210818.

The World Medical Association. 2016. Declaración de la AMM sobre el Uso de Animales en la Investigación Biomédica Adoptada por la 41 ${ }^{\text {a }}$ Asamblea Médica Mundial Hong Kong, septiembre 1989, revisada por la $57^{\text {a }}$ Asamblea General de la AMM, Pilanesberg, Sudáfrica, octubre 2006 y reafirmada por la 203 ${ }^{\text {a }}$ Sesión del Consejo de la AMM, Buenos Aires, Argentina, abril 2016. https://www.wma.net/es/policies-post/declaracionde-la-amm-sobreel-uso-de-animales-en-la-investigacionbiomedica/.

Vargas-Rodríguez L, Arroyo Figueroa G, Herrera Méndez CH, Pérez Nieto A, García Vieyra MI, Rodríguez Nunej JR. 2016. Propiedades físicas del mucílago de nopal. Acta Univ 26: 8-11.

WHO (World Health Organization). 2011. Quality control methods for medicinal plant materials. WHO/PHARM/92.559. Updated edition of Quality control methods for medicinal plant materials. WHO, Geneva.

Wisastra R, Arifin PF. 2020. Ex vivo evaluation of the mucolytic effect from a natural herbal combination of Echinacea purpurea, Sambucus nigra, Glycyrrhiza glabra, Vitex trifolia, and Zingiber officinale. Res J Pharm Biol Chem Sci 11: 109-115.

Zohra SF, Meriem B, Samira S. 2013. Some extracts of Mallow plant and its role in health. APCBEE Procedia. 5: 546-550. DOI: 10.1016/j.apcbee.2013.05.091.

Zhu X, Wang B, Zhang X, Chen X, Zhu J, Zou Y, Li J. 2010. Alphalinolenic acid protects against lipopolysaccharide-induced acute lung injury through anti-inflammatory and anti-oxidative pathways. Microb Pathog 142: 104077. DOI: 10.1016/j.micpath.2020.104077. 